\title{
Ecology of Wild Hogs in Florida ${ }^{1}$
}

William M. Giuliano and George W. Tanner²

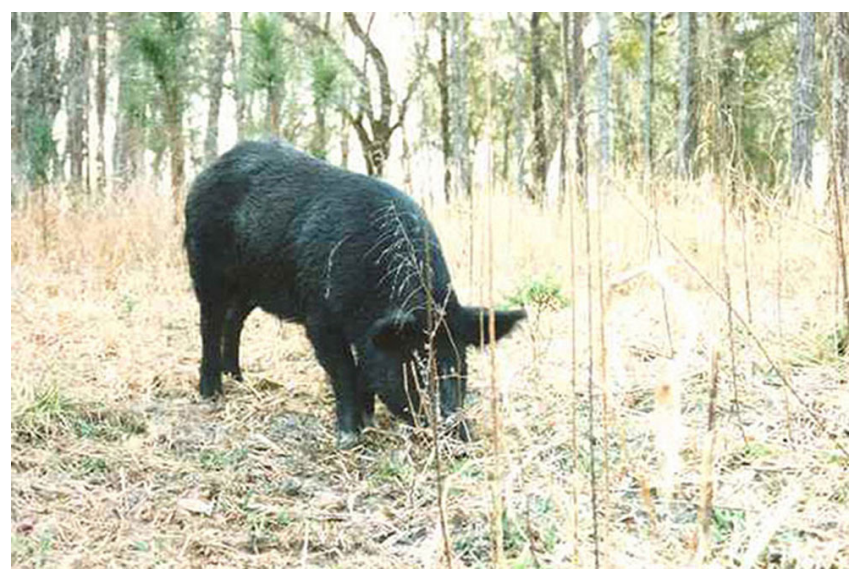

Figure 1. A wild hog foraging in a field. These animals are true pigs and not native to Florida or North America.

Credits: Photo by M.S. Smith.

\section{History, Distribution, and Abundance}

Florida's wild hogs (Figure 1) are often referred to as feral hogs or swine and are of three general types. These include free-ranging swine that come from domesticated stock, Eurasian wild boar, and hybrids of the two. Although technically, feral refers to free-ranging animals from domesticated stock, all wild hogs are typically referred to as feral in Florida and all are considered the same species, Sus scrofa. Wild hogs are in the family Suidae (true wild pigs), none of which are native to the Americas. Although not found in Florida, the only native pig-like mammal found in the United States is the collared peccary or javelina (Tayassu tajacu; Figure 2). These are not true pigs, in the family Tayassuidae, and about half the size of typical wild hogs.

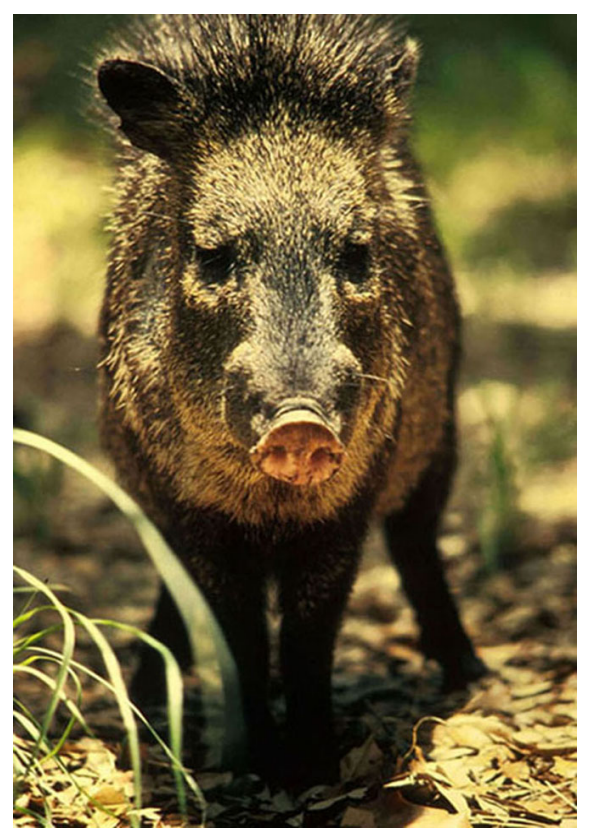

Figure 2. Although they look similar to wild hogs, peccaries are not true pigs. Not found in Florida, they are the only native, pig-like animal in North America. Credits: U.S. Fish and Wildlife Service/Photo by T. Stehn.

1. This document is WEC 191 and is one of a series of the Department of Wildlife Ecology and Conservation, Florida Cooperative Extension Service, Institute of Food and Agricultural Sciences (IFAS), University of Florida. First published: April 2005. Please visit the EDIS Web site at http://edis.ifas.ufl.edu for more publications.

2. William M. Giuliano is an Assistant Professor and Wildlife Extension Specialist; and George W. Tanner is a Professor; Department of Wildlife Ecology and Conservation, Cooperative Extension Service, Institute of Food and Agricultural Sciences, University of Florida, Gainesville, FL 32611.

The Institute of Food and Agricultural Sciences is an equal opportunity/affirmative action employer authorized to provide research, educational information and other services only to individuals and institutions that function without regard to race, color, sex, age, handicap, or national origin. For information on obtaining other extension publications, contact your county Cooperative Extension Service office. Florida Cooperative Extension Service/Institute of Food and Agricultural Sciences/University of Florida/Christine Taylor Waddill, Dean. 
It is believed that hogs were first brought to Florida, and possibly the U.S., in 1539, when Hernando de Soto brought swine to provision a settlement he established at Charlotte Harbor in Lee County. However, it is possible that hogs had been brought to the same site in 1521 by Ponce de Leon during a brief visit. During the next 4 centuries, explorers and settlers brought pigs with them throughout Florida. Many of these animals were given to or stolen by Native Americans who expanded pig numbers and distribution in the State. Europeans and Native Americans alike often raised their swine in semi-wild conditions (at least until the mid-1900s when open range ended and it became illegal) where hogs were allowed to roam freely and only rounded up when needed. Many of these animals and those escaping from captivity established feral populations throughout Florida. These feral populations have been further supplemented through deliberate releases of hogs in many areas by private individuals and the Florida Fish and Wildlife Conservation Commission to improve hunting opportunities (although the State no longer does this).

Eurasian wild boar were first released in the U.S. in New Hampshire in 1886. Boar were then released in New York (1900), North Carolina/Tennessee (1912), Texas (1919), Washington State (1981), and possibly other locations to provide a new, huntable big game species, and increase the sporting and trophy value of feral hogs through hybridization. Although most were released in enclosed areas, many escaped and readily hybridized with local feral hogs. A few Eurasian wild boar and many hybrids naturally dispersed to areas around release sites, including neighboring states. Hybrids have been trapped and moved to many parts of Florida by private individuals. In addition, the Florida Fish and Wildlife Conservation Commission has trapped and released feral hogs and hybrids in many areas to control hog-related problems in some areas and improve hunting opportunities in others. There are not believed to be any free-ranging, pure Eurasian wild boar in Florida, only feral hogs and hybrids.

Wild hogs are now found in every county in Florida and in at least 35 states and Canadian provinces, including most of the Southeast. Florida, second only to Texas, is estimated to have 500,000+ wild hogs in a relatively stable population, with 1 to 2 million in the Southeastern U.S. Some of the highest densities of hogs in Florida can be found north and west of Lake Okeechobee in areas with large forested tracts, dense understory vegetation, and limited public access. Hog numbers tend to be lower in areas with intensive agriculture and urbanization, and little water.

\section{Description}

All wild hogs are hoofed mammals, stocky with relatively short legs, long snouts ending in a disk, and long canine teeth that appear as tusks. Feral hogs resemble domestic hogs, but are usually leaner and have developed different behaviors that promote survival in the wild. Eurasian wild boar stand slightly taller but are approximately the same weight as feral hogs, and typically have longer hair (especially bristles), a leaner appearance, larger heads, and longer snouts. Coloration of feral hogs and Eurasian wild boar can vary. Feral hogs typically have solid-colored, black, white, and/or reddish-brown hair either in solid or mottled patterns across the body (Figure 3). The hair of Eurasian wild boar is typically brown at the base and light-tipped over most of the body, with some areas having brown or black, solid-colored hair. They also often have white-tipped hairs on the head forming a saddle-like patch of hair or streak of hair around the mouth. Hybrids have various combinations of feral hog and Eurasian wild boar characteristics. Appearance alone can be deceiving and is not considered a reliable means of determining whether a wild hog is of Eurasian wild boar decent, a feral hog, or a hybrid.

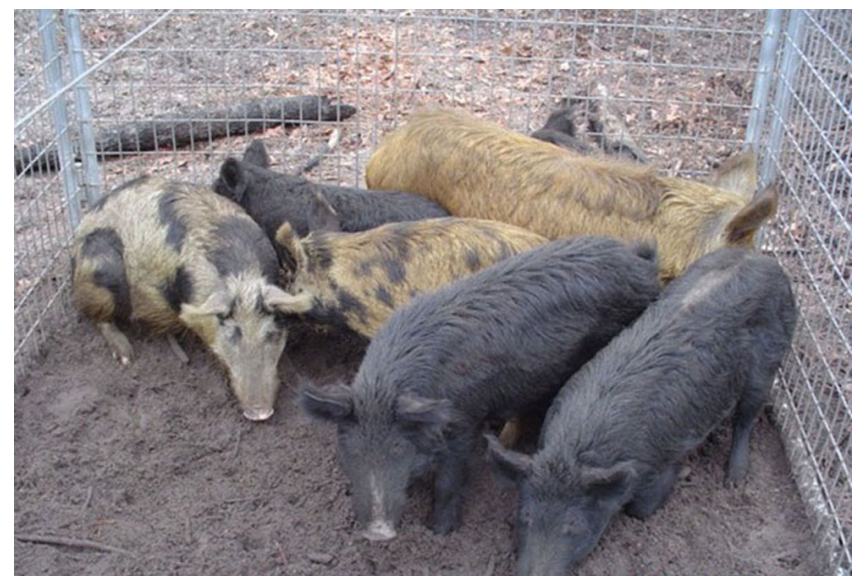

Figure 3. Wild hogs occur in a variety of colors. Credits: Photo by J. Allen. 
Wild hog size and weight are variable, and depend on genetics and local conditions. Typically, male hogs (called boars) are larger than females (called sows). Average adult males may weigh 200+ pounds, stand 3 feet at the shoulder, have tails reaching 12 inches, and are almost 5 feet from the tip of the tail to the tip of the snout. However, males greater than twice this size have been recorded. Hogs have 4 continually growing, self-sharpening tusks ( 2 in the upper and 2 in the lower jaw; the rubbing of upper and lower tusks keeps them sharp). Tusks in females are relatively small, while in males they become quite pronounced and have trophy value. Male hogs generally possess a thick hide on their shoulders (up to 3/4" thick) known as a hog shield that protects them during fights. All wild hogs have an excellent sense of smell and good hearing, but relatively poor vision. Wild hogs use a variety of vocalizations, including an alarm grunt given by the first hog to sense an intruder that causes a flight response by the rest of the herd. Other vocalizations are similar to domesticated pigs. Wild hogs also communicate through scent posts that are often also used for body-scratching and rubbing. Boars also "tusk" small trees, frequently pines, scraping off the outside bark with their tusks. This behavior may play a part in some type of dominance display. Such actions can seriously damage the rubbed objects, often trees (Figure 4).

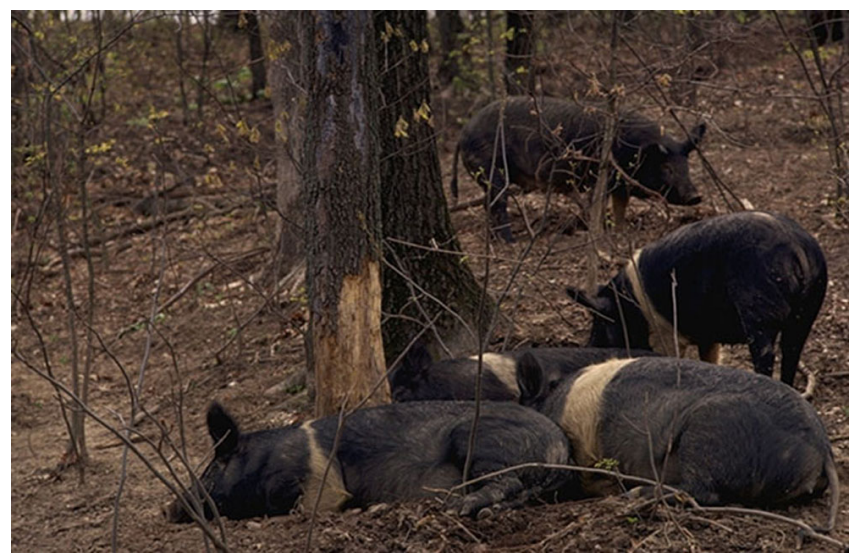

Figure 4. Wild hogs use objects, often trees, for body-scratching, and boars may "tusk" small trees as part of a dominance display. Credits: U.S. Department of Agriculture Photo.

Hog sign includes tracks, trails, wallows, rooting, rubbing, and scat (Figure 5).

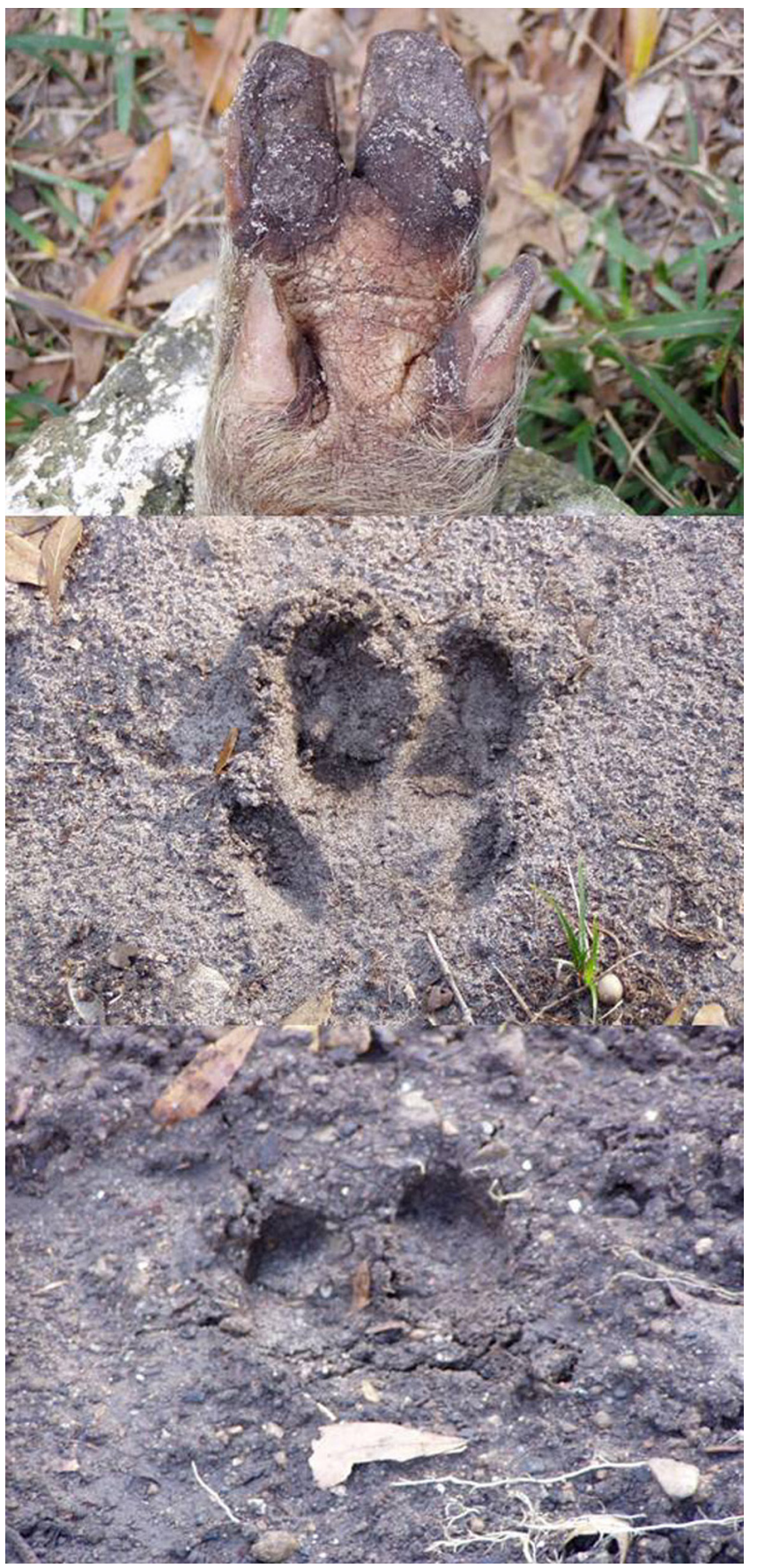

Figure 5. Wild hog feet and tracks are similar to those of domesticated pigs. Typically, the rear toes make little or no mark on the ground. Credits: Photos by C.L. Giuliano.

\section{Habitat Relationships}

Hogs use a variety of habitat types in Florida, from flatwoods, upland pine, and bottomland hardwood forests to coastal areas, marshes, swamps, and more open agricultural lands. However, hogs prefer large forested areas with abundant food, particularly acorns, interspersed with marshes, 
hammocks, ponds, and drainages; cover in the form of dense brush; and limited human disturbance. Dense cover is used as bedding areas and provides protection from predators and hunters (Figure 6).

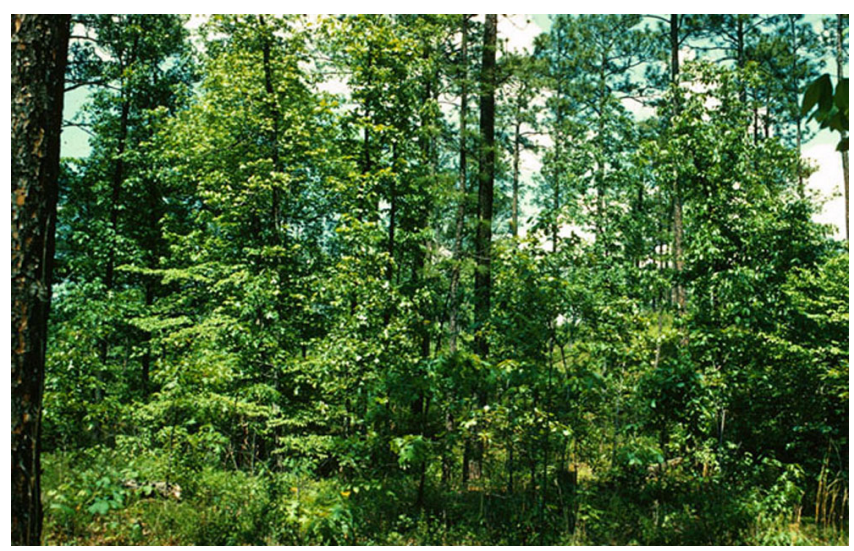

Figure 6. Wild pigs prefer to live in large tracks of forest with abundant food, dense understories, access to water, and little human disturbance. Credits: U.S. Department of Agriculture/Photo by W. Boyer.

The absence of water or wet soil conditions will eliminate or severely limit the use of an area by hogs. Wet conditions are important for hog wallowing in the warm climate of Florida. Hogs have poor physiological cooling mechanisms and keep from over heating by wallowing in mud and water (Figure 7). Wallowing also serves as a means of reducing ectoparasites, and will occur in almost any wet area. In cooler weather, hogs may seek open areas that allow maximum warming from the sun.

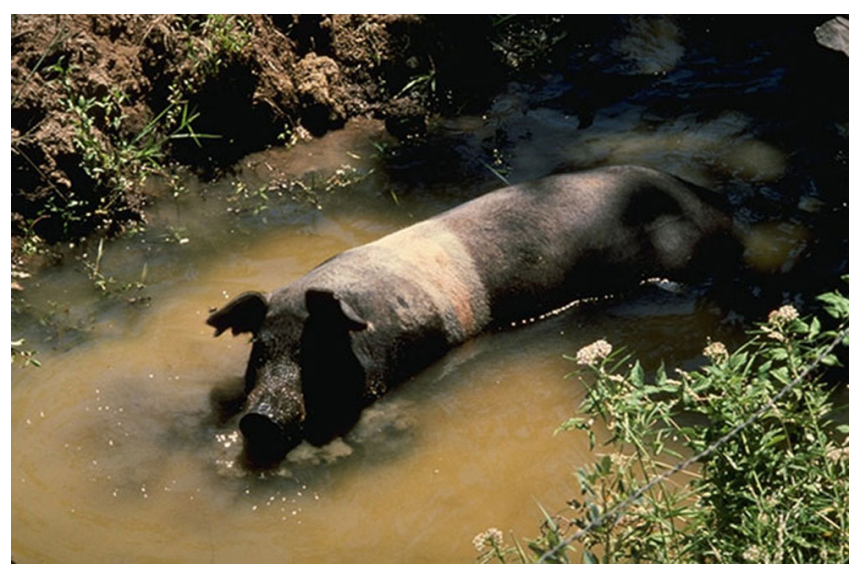

Figure 7. Wild hogs wallow to stay cool and reduce parasite infestation. Credits: U.S. Department of Agriculture Photo.

Seasonal changes in habitat use are typically related to food availability, with hogs preferring areas containing abundant hard mast (such as acorns and hickory nuts; Figure 8) and if unavailable, soft mast such as plums and other fruits.

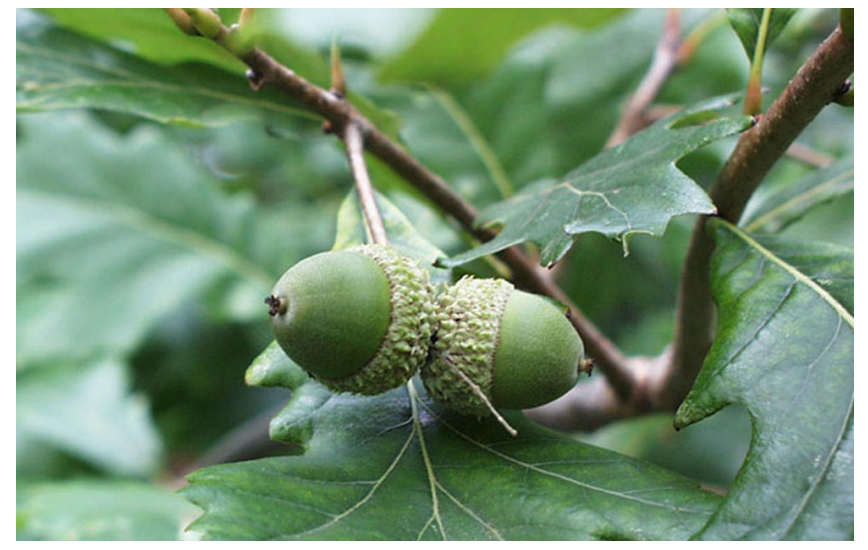

Figure 8. Although they are opportunistic and omnivorous feeders, the favorite food of wild hogs is acorns. Credits: U.S. Department of Agriculture/Photo by P. Wray.

Wild hogs are omnivorous, opportunistic feeders. However, they consume far more plant than animal material, and may occasionally consume carrion (dead animals). The list of foods eaten by hogs is diverse and includes grass, forb, and woody plant stems, roots, tubers, leaves, seeds, and fruits, fungi, and a variety of animals including worms, insects, crustaceans, mollusks, fish, small birds, mammals, reptiles, and amphibians. The opportunistic tendencies of wild hogs often lead them to forage in agricultural lands and forest plantations where they can cause significant losses of crops, including corn, rice, sorghum, melons, peanuts, forage grasses, grains, various vegetables, and tree seedlings. Wild hogs will also readily exploit game feeders, placed for deer, turkey, and other wildlife, and may destroy wildlife food plots by rooting (digging for foods below the surface of the ground).

\section{General Biology}

In Florida, wild hogs breed year round with peaks in the breeding cycle during fall and spring. Breeding activity includes courtship behavior, males fighting to achieve dominance and access to mates, and copulation. While hogs may be sexually mature at 6 months of age, they typically do not breed until about one year of age, provided there is good nutrition. Sows produce a "nest", which is usually a shallow depression in the ground, with or without vegetative nesting material, located in shaded, upland sites. With pregnancy lasting about 115 days, hogs 
can produce (farrow) 2 litters of 1-13 (usually 5-7) piglets per year, with the young usually born in a $1: 1$ male:female ratio. Piglets remain in the nest for 3 weeks, during which time they are frequently nursed by the sow. Piglets then begin to move with the sow away from the nest and progressively rely less on nursing for food. When sow nutrition is poor, reproduction may be reduced or delayed, and sows have been known to eat their young (Figure 9). Typically, boars are solitary animals except when breeding. However, sows (1-3) and their offspring travel in groups called sounders.

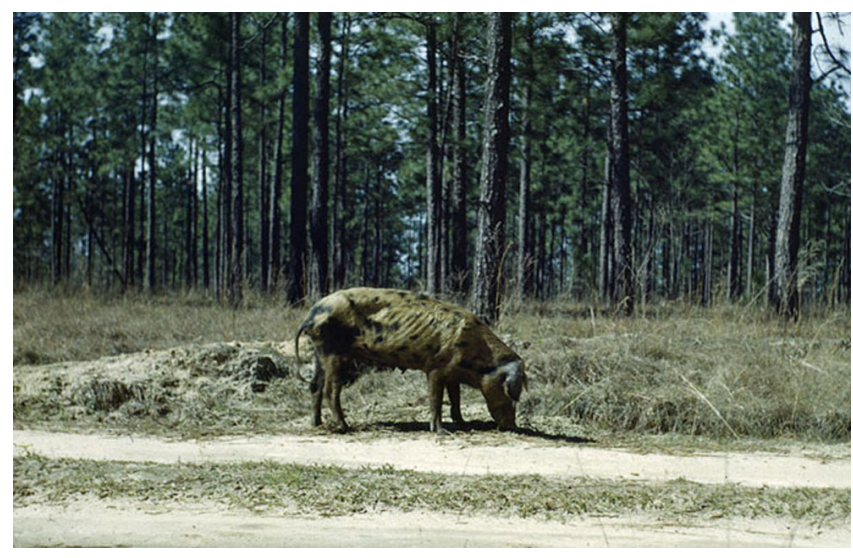

Figure 9. A female wild hog in poor condition forages along a road. Poor nutrition will lead to lower breeding success. Credits: U.S. Department of Agriculture/Photo by T.C. Crocker.

Although they breed much earlier, it may take 3-5 years until hogs are fully grown. Under good conditions, wild hogs usually live $4-5$ years, with some living $8+$ years. Hog mortality is greatest during the first 6 months of life, with predation, accidents, and starvation as leading causes of death during this time. As adults, hogs typically have higher survival rates, with hunting, a wide variety of diseases and parasites, and starvation as leading causes of mortality. Humans are the main predators of wild hogs, but large carnivores such as alligators, black bears, and Florida panthers may be capable of preying on adult animals (Figure 10). Piglets are also preyed upon by smaller predators including foxes, coyotes, and bobcats. When conditions are favorable, hog reproduction exceeds mortality leading to growing and overabundant populations.

Wild hogs typically range over 450-750 acres, but may range wider in search of food. During the cooler months of the year, hogs may be active and

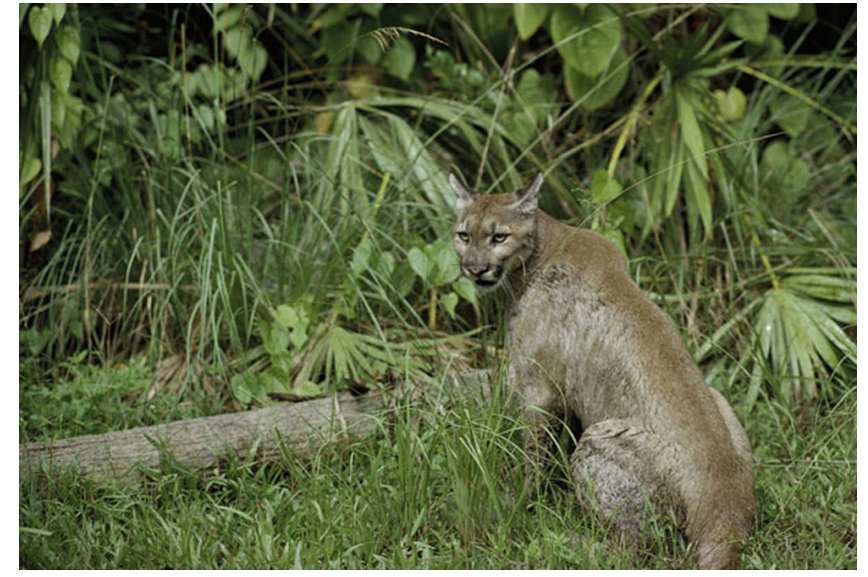

Figure 10. Humans are the primary predator of adult wild hogs. However, the Florida panther and other predators can easily prey upon younger animals. Credits: U.S. Fish and Wildlife Service/Photo by G. Gentry.

feed during both day and night. However, if hunting pressure or temperatures are high, they will seek cover during the day, and feed and be most active at night. Seasonal changes in activity are also related to breeding, with sows being less active and traveling over significantly smaller areas when piglets are in the nest, and males traveling over considerably larger areas in search of mates.

\section{Problems}

The opportunistic and omnivorous tendencies of wild hogs lead to many conflicts with people and wildlife. With hard mast as their preferred food, hogs directly compete with many popular game animals, including deer, turkeys, and squirrels. This competition is considered to be a significant limiting factor for populations of these native species in some areas. In addition, hogs may consume the nests and young of many reptiles (including sea turtles; Figure 11), ground-nesting birds, and mammals (including deer fawns). Wild hogs have also been known to consume young domestic livestock including poultry, lambs, and goats.

When natural foods are scarce or inaccessible, hogs will readily forage on almost any agricultural crop and feed set out for livestock and wildlife, leading to significant losses. Wild hogs will also feed on tree seeds and seedlings, causing significant damage in forests, orchards, and plantations. In Florida and the Southeast, this may be a serious 


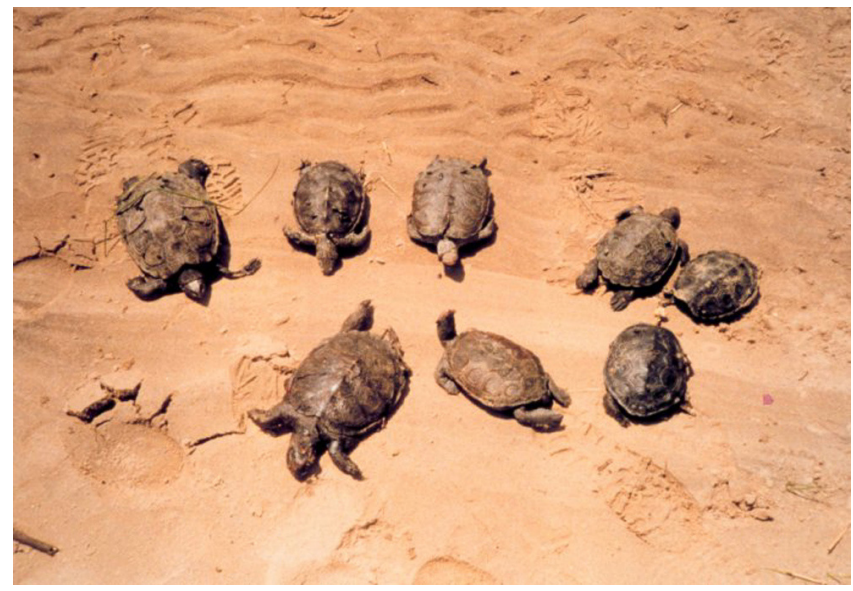

Figure 11. Hogs often prey upon the nests of ground nesting wildlife, including sea turtles. Credits: National Oceanic and Atmospheric Administration/Department of Commerce Photo.

problem in regenerating important long-leaf pine forests.

In addition to the effects of consuming, knocking down, rubbing, and trampling large amounts of native vegetation and crops, the rooting behavior of hogs also causes significant damage. Rooting destabilizes the soil surface, which can lead to erosion and exotic plant establishment; uproots or weakens native vegetation; and damages lawns, dikes, roads, trails, and recreation areas (Figure 12). They have also been known to damage fences and other structures. Wallowing behavior also destroys small ponds and stream banks, and can lead to declines in water quality.

Another area of concern is the potential for wild hogs to serve as reservoirs for many diseases and parasites that may affect native wildlife, livestock, and people. Hogs have been known to carry dozens of such pathogens, including cholera, psuedorabies, brucellosis, tuberculosis, salmonellosis, anthrax, ticks, fleas, lice, and various flukes and worms. Although not considered a serious threat to people, millions of dollars are spent each year to keep livestock safe from such problems.

Finally, hogs can be dangerous. Although wild hogs prefer to run and escape danger, if injured, cornered, or with young they can become aggressive, move with great speed, and cause serious injury (mainly with their tusks; Figure 13).

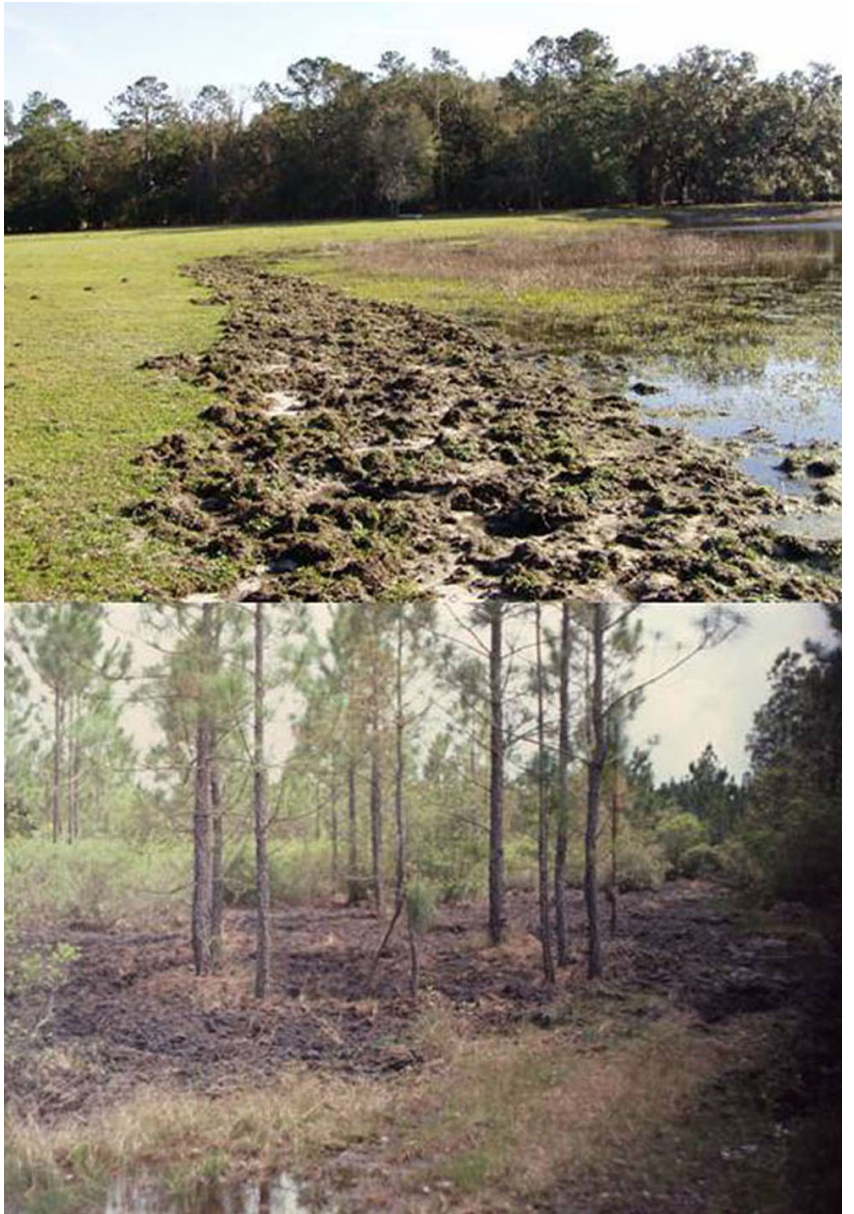

Figure 12. Rooting by wild hogs in search of buried foods can lead to erosion and water quality problems, as well as the destruction of native vegetation around ponds and in the forest. Credits: Top Photo by W.M. Giuliano; Bottom Photo by W. Frankenberger.

Information on control and management of wild hogs in Florida can be found at:

http://edis.ifas.ufl.edu/UW221 or through The Florida Fish and Wildlife Conservation Commission (http://www.floridaconservation.org).

\section{Additional Information on Wild Hogs:}

http://www.wildflorida.org/critters/hog.asp

http://texnat.tamu.edu/symposia/feral/feral14.htm

http://wildlifedamage.unl.edu/handbook/ handbook/allPDF/mam_d65.pdf

http://ector-co.tamu.edu/publications/11925.pdf 


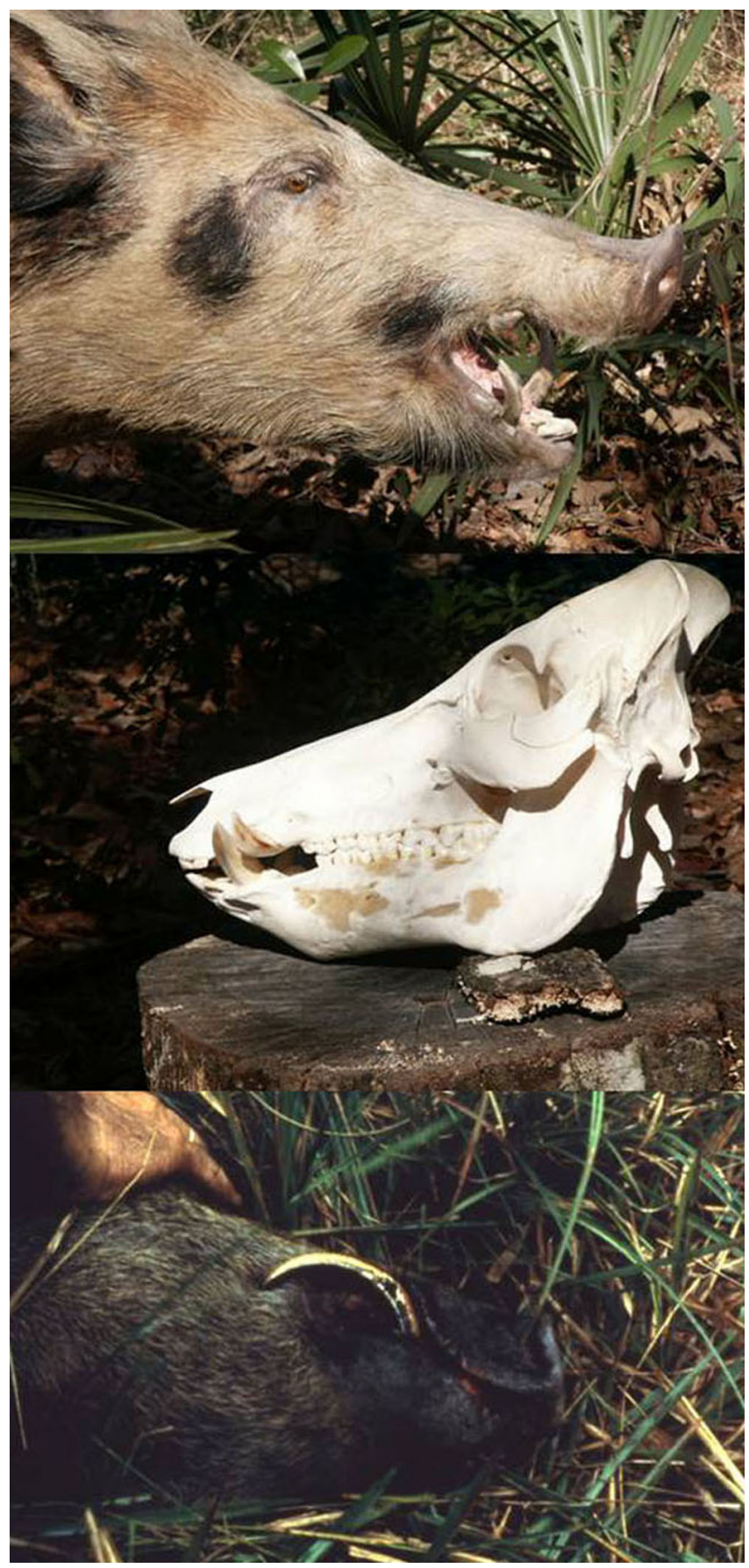

Figure 13. Wild hogs can be aggressive, and long, sharp tusks make them dangerous. Credits: Top Photos by J. Dunlap and M. Ludlow; Bottom Photo by W. Frankenberger.

http://www.noble.org/Ag/Wildlife/FeralHogs/03Current.htm

http://feralhog.tamu.edu/ 